\title{
Ontferming "beyond" vergeving als weg naar heling en heelheid: Een theoretisch model voor narratief pastoraat
}

\author{
Tiny van der Schaaf \& Yolanda Dreyer ${ }^{1}$ \\ Departement Praktiese Teologie \\ Universiteit van Pretoria
}

\begin{abstract}
Mercy beyond forgiveness as way to healing and wholeness: A theoretical model for narrative pastoral counselling

The article explores the model of Christie Neuger with regard to pastoral counselling with women who have been sexually violated in an ecclesial context. This model is complemented by the narrative philosophy of Paul Ricoeur. The article focuses on the following questions: What are the conditions for forgiveness? How can the abused woman find forgiveness in her heart? What is the role of the pastor? What happens if the woman cannot forgive? What are the theological implications of forgiveness? How can pastor and counselee together reframe the story of violence? The article argues that Ricoeur's notions of prefiguration, configuration and refiguration complement Neuger's theoretical model. This modified model presents a possible way to healing and wholeness.
\end{abstract}

\footnotetext{
Geef geloof aan wie Gij zendt, hoop en liefde, dat op 't eind, wat met tranen werd gezaaid, met gejuich mag zijn gemaaid. Erbarm U Heer.
}

(Gezang 313:5 LvdK)

\section{TWEEMAAL SLACHTOFFER}

De laatste jaren komt er steeds meer openheid in de kerk over seksueel misbruik wat plaats vindt binnen de kerkelijke gemeenschap. Toch blijkt het

\footnotetext{
${ }^{1}$ Tiny van der Schaaf, theologiestudent aan de Vrije Universiteit, Amsterdam heeft onderzoek voor dit artikel gedaan aan de Universiteit van Pretoria in 2004 onder de leiding van Prof dr Yolanda Dreyer.
} 


\section{Ontferming "beyond" vergeving als weg naar heling en heelheid}

binnen kerkelijke gemeenschappen lastig een dergelijke situatie te hanteren wanneer deze zich voordoet. Naast alle praktische problemen die ontstaan wanneer dader en slachtoffer ${ }^{2}$ deel uitmaken van dezelfde kerkelijke gemeenschap, is er de vraag naar pastorale begeleiding. Hoe kan een pastor het slachtoffer op de juiste manier begeleiden ${ }^{3} \mathrm{Er}$ is gebleken dat vrouwen die naar een geestelijke gaan voor hulp in geval van misbruik langer bij degene die hen misbruikt blijven en de misbruik wordt niet minder (Adams 1994:5).

Vrouwen die pastorale hulp zoeken na misbruik, krijgen vaak het advies om te vergeven en te vergeten. Als een slachtoffer vergeeft is ze meer christen, heiliger (zie Neuger 2001:101). Het is onchristelijk om niet te vergeven (LC 17:3; Kol 3:13). Slachtoffers worden onder andere herinnerd aan het feit dat God alle zonden vergeeft. Andere bijbelteksten die vaak in dit verband gebruikt worden, zijn Matteüs 18:21-35 waarin Jezus antwoord geeft op de vraag van Petrus hoe vaak hij zijn broeder moet vergeven en Lucas 23:34 waar Jezus aan het kruis de mensen vergeeft die Hem dit aandoen. Wanneer vrouwen een dergelijke boodschap meekrijgen, is dat een ontkenning van wat hen aangedaan wordt, want wanneer ze de dader blijven vergeven kan de situatie van misbruik blijven bestaan.

Als pastors een vrouw die misbruikt werd (wordt) adviseert om te vergeven, vervangen zij het praktische antwoord met een religieus antwoord. Vergeving in de afwezigheid van berouw bij de dader is een zalf voor het geweten van pastors, maar niet een helende ervaring voor deze vrouwen en zeker niet veilig. Op die manier staat vergeving in dienst van de pastor en niet van het slachtoffer en de dader. "You (the battered woman) forgive so that I (the minister) can forget about it" (Adams 1994:5). Vergeven is voor vele vrouwen die de ervaring van misbruik hebben gehad een moeilijk punt. Naast alle woede, verdriet en machteloosheid kan er een schuldgevoel ontstaan over het feit dat ze niet kunnen vergeven (vgl Heitink 1990:77). Zo zijn ze tweemaal slachtoffer geworden.

In dit onderzoek maken wij gebruik van de theorie van Christie Neuger. Zij beschrijft in haar boek een pastoraal narratieve benadering van het counselen van vrouwen. Zij haalt het begrip vergeving aan als een theologisch probleem in het pastoraat (Neuger 2001:101). Zij noemt echter alleen "externe voorwaarden" voor vergeving. Onder externe voorwaarden verstaan wij de voorwaarden waaraan de dader moet voldoen en die daardoor niet binnen het bereik van de vrouw die tot slachtoffer gemaakt werd, liggen. Enkele voorbeelden hiervan zijn: de dader moet berouw hebben; de dader

\footnotetext{
${ }^{2}$ In dit onderzoek beperken wij ons tot vrouwelijke slachtoffers.

${ }^{3}$ In dit onderzoek gaan wij uit van het perspectief van het slachtoffer. Wij realiseren ons dat ook voor de dader pastorale hulp noodzakelijk kan zijn.
} 
moet verantwoordelijk gehouden worden, en er moet een "change of mind" plaats gevonden hebben bij de dader. Neuger schrijft niet over de plaats van de vrouw die tot slachtoffer gemaakt werd in dit geheel. Wat zijn de interne voorwaarden voor vergeving? Wat kan deze vrouw doen om tot vergeving te komen? Wat is de plaats van de pastor in dit geheel? Wat gebeurt er met de christenvrouw wanneer zij niet kan vergeven? Wat zijn de theologische implicaties van vergeving? Kortom, hoe kunnen pastor en pastorant achter het verhaal van het slachtoffer komen, zodat er reframing van dit verhaal kan plaatvinden?

In dit onderzoek kijken wij naar hoe pastors in het pastoraat met betrekking tot het begrip vergeving, samen met het slachtoffer "beyond" het verhaal kunnen komen, zodat de vrouw kan komen tot heling en heelheid. Vragen die hier aan de orde komen, zijn:

- Welke bijbelse en theologische notities spelen bij pastors een rol in de begrippen recht doen en vergeving?

- Met welke gevolgen?

Het doel van dit onderzoek is om een handvat te creëren voor pastoraat met vrouwen die slachtoffer zijn gemaakt van seksueel geweld binnen de kerkelijke gemeenschap en die worstelen met het begrip vergeving. Wij bespreken deze zaak in twee opeenvolgende artikelen. In het eerste artikel word de theorie van Neuger uitgewerkt en gespiegeld aan de filosofie van Paul Ricoeur.

In het tweede artikel (zie Van der Schaaf \& Dreyer [2004]) word een bijbels-theologisch model vanuit het Mattheüsevangelie beschreven. Daarin worden de begrippen schuld en vergeving belicht. De reden dat voor het Mattheüsevangelie is gekozen, is dat Mattheüs de eis om te vergeven als een imperatief van Jezus stelt (zie het Onze Vader gebed in Mt 6:12). Jezus legt volgens Mattheüs met de gelijkenis van de koning en de schuldeiser aan Petrus uit dat vergeving onvoorwaardelijk gegeven moet worden, zeventig maal zeven. Dit perspectief op goddelijke vergeving geeft voor veel vrouwen die tot slachtoffer gemaakt zijn, problemen. In het tweede artikel wordt er een richtlijn voor de uiteindelijke reframing als weg tot heling en heelheid gegeven.

\section{EEN THEORETISCH MODEL VOOR NARRATIEF PASTORAAT}

Het theoretische model waar wij gebruik van maken is dat van Christie Neuger. Zij heeft vanuit feministisch oogpunt een raamwerk ontworpen voor het pastoraal counselen van vrouwen via de narratieve methode. In de eerste 


\section{Ontferming "beyond" vergeving als weg naar heling en heelheid}

paragraaf zullen wij ingaan op het begrip feminisme en waarom ook wij kiezen voor feministisch uitgangspunt. Daarna volgt een beschrijving van de narratieve methode en het doel van een theorie voor counseling met tot slot de plaats van de theologie in deze theorie. Ook wordt een filosofische onderbouwing voor het raamwerk van Neuger gegeven vanuit het gezichtspunt van Paul Ricoeur.

\subsection{Feministisch oogpunt}

De reden voor de keuze van een feministisch model komt voort uit het feit dat dit onderzoek gericht is op pastoraat met vrouwen - vrouwen die slachtoffer zijn gemaakt van seksueel geweld. Riet Bons-Storm (1992:11) geeft de volgende definitie van feminisme: “'Feminisme' betekent dat men bij het waarnemen van de werkelijkheid de maatschappelijke positie en zienswijze van vrouwen serieus neemt."

Vrouwen zitten vandaag de dag steeds in een ondergeschikte positie. Overal zijn nog patriarchale structuren, in het klein in het gezin en de familie, maar ook in grotere structuren zoals kerk en maatschappij. Er is op vele fronten sprake van machtsongelijkheid. Vrouwen leven in een wereld waar ze minder waard geacht zijn dan mannen. Dit komt door hun sekse (Neuger 2001:16). Er zijn meerdere consequenties hiervan. Het komt steeds voor dat vrouwen minder verdienen dan mannen die een zelfde baan met vergelijkbare taken hebben (vgl Holder \& Anderson 1989:357-380). Daarnaast is uit onderzoek gebleken dat vrouwen die voltijd werken daarnaast nog 70 procent van het huishoudelijk werk doen (zie Neuger 2001:19). De cijfers betreffende mishandeling en verkrachting van vrouwen in de Verenigde Staten zijn schrikbarend hoog. De politie heeft geweld in huiselijke kring ten opzichte van vrouwen lang geaccepteerd. Vanuit de traditie bestond namelijk het beeld dat vrouwen aan hun man "toebehoren" en dat het een zaak van "discipline" is (Neuger 2001:21).

Dit beeld van machtsongelijkheid wordt uitgewerkt door James Nelson (1988:37) wanneer hij het "ladderdenken" beschrijft. Een ieder heeft haar of zijn eigen plaats op de ladder. Hoe hoger men op de ladder staat des te groter is de mogelijkheid om anderen te beïnvloeden. Men is in staat de marge van vrijheid te bepalen van diegenen die lager staan. Bons-Storm (1992:50) gebruikt het woord "subject-kwaliteit", dat wil zeggen de mate waarin iemand zeggenschap heeft over zichzelf. Hoe lager de positie op de maatschappelijke ladder, des te kleiner is de subject-kwaliteit. In dit ladderdenken zijn vrouwen in een afhankelijke positie. Dat betekent dat hun subject-kwaliteit beperkt wordt en soms zelfs helemaal genegeerd wordt. Een vrouw zal niet op de hoogste sport van de ladder komen. 
De theologie houdt dit ladderdenken mee in stand. Alles draait om God de Vader en Jezus de Zoon. Vrouwen moeten zich uitdrukken in een taal die hun van bovenaf is opgelegd. De bijbel wordt vaak gebruikt als argument om de onderdanige positie van de vrouw te rechtvaardigen. Ook in pastorale relaties is er sprake van ladderdenken. Pastors staan hoger op de ladder: blanke man, hetero, universitaire graad. Vrouwen wanen zich vaak onder de pastor en niet naast de pastor. Op die manier is er dus sprake van machtsongelijkheid. Als zij binnen het ladderdenken blijven, zullen pastors domineren in de pastorale sessies, niet omdat zij dit zo graag willen, maar omdat hun positie dit met zich meebrengt (Bons-Storm 1992:66-67). Zo blijven in het kerkelijke pastoraat vele verhalen over incest en seksueel geweld ongehoord. Dit zijn dingen die niet gezegd mogen worden.

Het is belangrijk voor het welzijn van vrouwen om vrouwen hun subject-kwaliteit terug te laten winnen en dat men de zienswijze van vrouwen serieus neemt. Daarom is er in dit onderzoek gebruik gemaakt van een narratief model vanuit feministisch oogpunt.

\subsection{Raamwerk voor pastorale counseling via de narratieve methode}

De narratieve methode vanuit het gezichtspunt van Neuger (2001) maakt gebruik van de psychologische en theologische discipline. Deze twee disciplines zijn weer onder te verdelen in drie hoofdpunten. Het eerste punt bevat de persoonlijkheidstheorieën die ons helpen na te denken over de manier waarop mensen een zelfbesef vormen. Dit gaat om een zelfbesef in een gemeenschap, maar ook een besef van hoe ze op zichzelf zijn, om zich zo te verbinden met de wereld en die wereld te antwoorden. Het tweede punt geeft een inleiding in de ontwikkeling van de theorie van berading (psychotherapeutisch), die het proces van verandering van mensen en hun gedrag bestudeert. Wanneer het zelfbesef en de wereld met elkaar botsen, ontstaan er problemen. Hoe gaan mensen om met het veranderen van hun eigen waarnemingen, tussen anderen, en hun manier van zijn in de wereld? Het derde punt verkent deze positie in de context van de theologie waar het gaat om wat mensen of gemeenschappen geroepen zijn om te zijn.

\subsubsection{Persoonlijkheidstheorieën}

In de psychologische persoonlijkheidstheorieën wordt aan vrouwen geen recht gedaan. Deze theorieën echter hebben wel een grote invloed op de manier waarop mensen kijken naar het vormen van een zelfbesef bij vrouwen en hoe zij zich verbinden met de wereld. Dit heeft als gevolg dat er een onjuist beeld bestaat over vrouwen. Neuger (2001:38-40) heeft acht kritiekpunten op de persoonlijkheidstheorieën die tot dusverre gebruikt zijn: 


\section{Ontferming "beyond" vergeving als weg naar heling en heelheid}

- In deze door mannen gedomineerde cultuur zijn de ervaringen van vrouwen weggelaten bij het maken van theorieën. De mannelijke cultuur is als norm genomen. Vrouwen worden gezien als probleem omdat ze anders zijn dan mannen.

- $\quad$ Een leemte in de persoonlijkheidstheorieën is dat er geen adequate definitie van mentale gezondheid bij vrouwen bestaat.

- $\quad$ De bron van het probleem wordt bij de pastorant en in haar relaties gelegd (vgl ook Greenspan 1983). Er wordt geen goede socioculturele analyse gemaakt.

- De meeste persoonlijkheidstheorieën zijn op pathologie georiënteerd. Er wordt nadruk gelegd op de problemen en niet op de eigen kracht. Deze problemen ontstaan echter vaak door aanpassend/overlevend gedrag. Dit staat in verbinding met het vorige punt: er is geen socioculturele analyse waaruit zichtbaar wordt waar het aanpassende gedrag uit voortkomt.

- $\quad$ Problemen worden vaak fout gediagnostiseerd.

- $\quad$ Uit praktisch oogpunt duurt het counselen vaak lang en kost veel geld. Vele vrouwen kunnen zich dat niet permitteren.

- Vele counselingstheorieën zijn schikkingsgericht. Therapeuten laten vrouwen schikken in hun situatie. Dit is niet ethisch.

- $\quad$ De meeste theorieën zijn niet kritisch ten opzichte van hun eigen vooronderstellingen, sociale locaties en filosofieën. Dit is cruciaal voor het bouwen van een pastorale theorie voor het counselen van vrouwen.

Uit het voorgaande blijkt dat het belangrijk is om voor een nieuwe theorie de ervaringen van vrouwen als centrum te nemen. Men moet sexisme, rascisme, klassisme en de dominante heteroseksuele context waarin vrouwen leven serieus nemen. Vrouwen moeten worden verstaan vanuit een individueel en relationeel perspectief. Dit gebeurt in het paradigma van Ballou \& Gabalac (1985). Ze noemen hoe vrouwen overleven in zo een context "harmful adaptation." Zij doen de suggestie dat vrouwen in een seksistische wereld worden geboren, waarin hen geleerd wordt om zich aan te passen. Deze aanpassing is schadelijk voor vrouwen. De ontwikkeling begint al bij de geboorte en is een doorgaande spiraal, tenzij er een interventie voorkomt. Zij beschrijven dit model in vijf fasen (Ballou \& Gabalac 1985:81-97):

- $\quad$ Het eerste element van de spiraal is "humiliation". Dat houdt in dat vrouwen zich minderwaardig ervaren door hun eigen ogen en door de ogen van anderen. Dit kan een chronisch proces zijn, maar dit kan ook in een acute situatie voorkomen. Een voorbeeld van chronische 
vernedering is te vinden in het eerste hoofdstuk van het boek van Neuger (2001:1-32), waarin zij de beelden van de media over vrouwen beschrijft. Een voorbeeld van acute vernedering is incest.

- $\quad$ De tweede fase is "inculcation". In deze fase wordt aan meisjes en vrouwen geleerd wat het is om vrouw te zijn. In de eerste fase hebben ze al ervaren wat het is om minder waard te zijn. Nu worden er regels toegevoegd voor het vrouw zijn, over wat wel mag en wat niet. Een voorbeeld hiervan is dat een vrouw niet beter mag presteren dan een man tot wie ze zich aangetrokken voelt.

- $\quad$ De derde fase is "retribution". Dit is de straf wanneer vrouwen de regels breken van het vrouw-zijn. Dit kunnen subtiele straffen zijn zoals het geven van namen als "kenau" of "heks". Deze straffen kunnen oplopen tot het plaatsen van vrouwen onder controle van een psychiatrisch systeem of een nog hardere straf zoals mishandeling. Het doel van deze fase is het uitdoven van de wens van vrouwen de regels te willen breken. Deze fase wordt goed geïlustreerd in de Friese film "Nynke"4 over het leven van de schrijfster Nynke van Hichtum.

- $\quad$ De vierde fase wordt in dit paradigma "conversion" genoemd. In deze fase internaliseren vrouwen de boodschap dat ze zijn zoals hen verteld is te zijn en ze geloven dat de regels die ze hebben geleerd waar zijn. Deze vrouwen geloven bijvoorbeeld dat ze gemaakt zijn om onzelfzuchtig anderen te dienen. Met deze vierde fase is het model nog niet afgesloten omdat er nog steeds vrouwen zijn die het onrecht aan de kaak stellen. Deze vrouwen veroorzaken ongemak en conflicten in de bekeerde vrouwen.

- $\quad$ Zo ontstaat de vijfde fase "conscription". Dit is de fase waarin "bekeerde" vrouwen proberen om de vrouwen die de bron van hun ongemak zijn "vrijwillig te verplichten" om terug te keren tot traditioneel denken over vrouwen en zich te bekeren van hun "dwaalwegen". Hun "probleem" is dat zij zich bewust zijn van het patriarchale systeem en ervoor strijden dat bij het waarnemen van de werkelijkheid de maatschappelijke positie van vrouwen en hun zienswijze serieus worden genomen (vgl Bons-Storm 1992:11).

Tot slot is het nog belangrijk om erbij te vermelden dat er verschillen bestaan in de situaties van vrouwen door ras en klasse. De regels en straffen zijn afhankelijk van de sociale locatie van vrouwen.

Vervolgens zal dieper ingegaan worden op een narratieve methode die gebaseerd is op het werk van van David Epston \& Michael White (1990).

${ }^{4}$ Nynke, een liefdesgeschiedenis, geregisseerd door P Verhoeff, 2001. 


\section{Ontferming "beyond" vergeving als weg naar heling en heelheid}

Daarnaast volgt er een uitleg waarom deze methode geschikt is voor het counselen van vrouwen.

\subsubsection{Theorie voor counseling}

\subsubsection{De narratieve methode}

Narratieve therapie theorie is gebaseerd op postmoderne/poststructuralistische filosofieën die ervan uit gaan dat onze interpretatie van de realiteit, de realiteit is. Deze realiteit is sociaal geconstrueerd, dat wil zeggen ze is geordend en wordt in stand gehouden door persoonlijke, familie- en culturele verhalen. Freedman \& Combs (1996:1) maken gebruik van de sociaal-constructionistische metafoor. Deze metafoor maakt ons attent op de wijze waarop de sociale en interpersoonlijke realiteit van iedere persoon tot stand is gekomen en tot stand komt, namelijk door interactie met andere mensen en instituten. De sociale realiteit heeft een grote invloed op de betekenis van levens van mensen.

Een groot deel van de taak van een narratieve pastor is mensen te helpen om een nieuwe taal, een nieuwe manier van interpreteren en zo een nieuwe realiteit te creëren. Hoe mensen de ervaringen die ze hebben, verbinden met de context waarin deze ervaringen voorkomen, is fundamenteel voor de manier waarop ze vooruitbewegen in hun leven en hun toekomstverhalen bouwen. De narratieve theorie erkent dat mensen niet alleen hun eigen verhalen waarin ze leven creëren en betekenis geven, maar dat mensen ook karakters zijn in de verhalen van andere mensen, systemen en culturen. Wanneer er een verandering plaatsvindt in de verhaallijnen of de interpretatielenzen van een van deze mensen (individu, systeem of cultuur), dan heeft dat gevolgen voor alle anderen. Wanneer pastors gebruik maken van narratieve therapie, proberen zij de persoon te helpen met het identificeren van het verhaal wat de problemen veroorzaakt. Een aantal kenmerken van de narratieve methode zijn:

\section{- Deconstructie van de discourses van de dominante verhalen} Deconstructief luisteren wordt door Freedman \& Combs omschreven als een poging om ruimtes te openen voor aspecten van het leven van mensen die nog niet "verhaald" zijn. Voorbeelden hiervan zijn ervaringen die in strijd zijn met dominante discourses als de patriarchale cultuur, seksisme en rascisme. De dominante discourses bepalen grotendeels de positie van de vrouw in het gezin, de kerk en de samenleving. Ervaringen die in strijd zijn met de dominante discourses en vaak nog niet "verhaald" zijn, hebben wel een grote 
invloed op de verhalen van vrouwen. Het is noodzakelijk de dominante discourses te deconstrueren om ruimte te scheppen voor een nieuw verhaal. Volgens de filosoof Jacques Derrida (1978:102-117) is de betekenis van ieder symbool, woord of tekst altijd in een meervoudige plurale, heterogene werkelijkheid ingebed. Er is niet één ware betekenis, omdat ieder mens haar of zijn eigen context heeft. Het luisteren naar verhalen van mensen wordt dan ook geleid door het idee dat deze verhalen vele verschillende betekenissen kunnen hebben. leder mens kan de betekenis veranderen zodat er een andere context ontstaat (Freedman \& Combs 1996:46).

\section{- $\quad$ Externalisatie van het probleem}

G Monk (1997:26) beschrijft de externalisatie van het probleem als volgt: mensen zijn mensen en problemen zijn problemen. Niemand is een probleem in zichzelf. Hierdoor verandert de realiteit. Een depressieve persoon wordt een persoon met depressiviteit. Dit is een kleine grammaticale verandering met grote gevolgen. De tendens van de pastorant om zichzelf de schuld te geven wordt ondermijnd. De pastor en de pastorant staan aan dezelfde kant van het probleem. Er is geen onderscheid tussen de "gezonde" pastor en de "zieke" pastorant. Er wordt samengewerkt om het probleem te verkleinen. $\mathrm{Er}$ is geen sprake van hiërarchie. De pastor is niet meer dominant. Het is de bedoeling dat pastoranten zelf hun kracht en bronnen ontdekken, dat het probleem een begin had en dus ook een einde heeft.

\section{- "Unique outcomes"}

Een andere manier om pastoranten zich bewust te laten worden van hun eigen kracht is door hen te laten ontdekken dat zij zelf de autoriteit hebben om te veranderen. Epston \& White (1990:16) noemen dit de "discovery of the unique outcomes." Zij doelen dan op de aspecten van de beleefde ervaring die buiten het dominante verhaal van de pastorant vallen. Het zijn sporen van oplossingen in het verhaal van de pastorant. Het is de bedoeling dat de pastor de pastorant op die gelegenheden wijst, wanneer de pastorant iets goed gedaan heeft of wanneer iets gelukt is. Epston \& White achten het belangrijk dat wanneer mensen "problem-saturated" (probleemverzadigd) zijn, ze ervan bewust worden gemaakt dat ze de potentie hebben om iets te veranderen. Op die manier ontdekken mensen dat zij zelf de autoriteit in handen hebben. 


\section{Ontferming "beyond" vergeving als weg naar heling en heelheid}

- Verbinding verleden-heden-toekomst

Verleden, heden en toekomst zijn in de narratieve methode onlosmakelijk met elkaar verbonden. Wanneer mensen "problemsaturated" bij een pastor komen zÿn het heden en de toekomst duister. Dit komt door de verhalen van het verleden. Wanneer de pastor op "unique outcomes" wijst in het verhaal zal de pastorant meer ruimte ervaren en in staat zijn het verhaal van het verleden te "reframen". Door deze herinterpretatie van de verhalen van het verleden onstaat er een nieuwe ervaring van het heden en nieuw zicht op de toekomst (Simms 2003:86). Epston \& White (1990:10) geven de volgende omschrijving: "Since all stories have a beginning (or a history), a middle (or a present), and an ending (or a future), then the interpretation of current events is as much future-shaped as it is past-determined."

\section{- Taal}

Mensen hebben taal nodig om betekenis te geven aan ervaringen. Wanneer een ervaring niet geïnterpreteerd wordt, dat wil zeggen onder woorden gebracht wordt, dan is die ervaring betekenisloos. Het gebruik van taal, woorden geeft betekenis aan ervaringen (Müller 2000:13). De betekenis van een woord wordt niet gedragen door het woord zelf. Woorden krijgen betekenis door hun context. Geen context is echter hetzelfde, daarom moet over de betekenis van woorden worden onderhandeld. De taal die we gebruiken, vormt onze wereld en opvattingen. De enige werelden die mensen kunnen kennen, zijn de werelden die we delen in taal. Door taal die mensen leren, ontstaat een verschillende kijk op de wereld en daardoor leren mensen verschillende dingen. Taal vertelt ons hoe om de werld te zien en wat daarin is (Freedman \& Combs 1996:28). Doordat mensen taal leren in een verschillende context en daardoor dingen verschillend interpreteren, is het belangrijk dat pastors checken wat de pastorant bedoelt én dat zij zich aanpassen aan de taal van de pastorant.

\section{- $\quad$ Not-knowing position}

Een ander belangrijk aspect van het narratief counselen is de "notknowing position". Dit is de streefpositie van de pastor. Volledige "objectiviteit" is uiteraard niet mogelijk, want iedere pastor draagt haar of zijn eigen verhaal met zich mee. Het doel van de "not-knowing position" is dat de pastorant de eigenlijke deskundige wordt. De inzet van pastors blijft belangrijk en uiteraard wordt er van het feit uitgegaan dat zij deskundigen zijn. De kunde is daarin gelegen dat pastors het 
verloop van het proces van veranderingen kent en een eerlijke nietwetende positie inneemt. Zij kennen het verhaal van de pastorant immers niet. Het is de kunst de pastorant te machtigen tot de deskundige (Müller 2000:17). Deze theorie slaat een brug tussen individuele en systeemgeoriënteerde theorieën en tussen probleemgefocusde en oplossinggefocusde benaderingen en tussen directief en non-directief counselen. Wanneer pastoranten zelf het proces leiden, helpt het hen om hun sterke kanten te vinden en te ontwikkelen in plaats van zich te focussen op hun "pathologie" of open wonden die niet kunnen genezen.

Narratieve counseling bestaat dus uit deconstructieve en reconstructieve gesprekken waarin de pastor vanuit een "not-knowingposition" commentaar geeft, vragen stelt en op een positieve manier problemen probeert te reframen. De pastor externaliseert het probleem van de pastorant en zoekt meegaande in de taal van de pastorant naar de "unique outcomes" in het verhaal van de pastorant. Op die manier wordt het probleem narratief ontwricht en wordt er een verbinding gelegd met behulpzame bronnen in de pastorant zelf die voorheen genegeerd werden. Door het reframen van het verhaal van het verleden onstaat er een nieuw heden en nieuw zicht op de toekomst.

\subsubsection{Doel van een theorie voor counseling}

Het doel van een theorie voor counseling is het beschrijven van het proces waarin een opzettelijke verandering kan plaatsvinden in een persoon of groep die deze verandering zoeken in relatie met een of meerdere helpende personen. Dit proces heeft twee aspecten. In de eerste plaats moeten de dynamieken van het proces begrepen worden. Wanneer dat gedaan is, ontstaat er de ruimte om effectieve oefeningen te verbinden met deze dynamieken, zodat de veranderingen vergemakkelijkt worden. We hebben dus de voorwaarden voor veranderingen én de processen waarin de veranderingen het meest effectief verlopen.

De voorwaarden voor verandering hebben pragmatische en ethische componenten. Bij de pragmatische componenten kunnen we de vraag stellen: onder welke omstandigheden heeft de gewenste verandering de meeste kans om plaats te vinden? En bij de ethische componenten de vraag: wat garandeert dat deze verandering gewenst en behulpzaam is voor de persoon die het zoekt?

Eerst worden de voorwaarden voor verandering verkend. Daarna wordt er dieper ingegaan op de dynamiek van de verandering. 


\section{Ontferming "beyond" vergeving als weg naar heling en heelheid}

\section{- Voorwaarden voor verandering}

Een belangrijke voorwaarde voor verandering zijn de karakteristieken van de pastor zoals warmte, acceptatie en positief respect gericht op de pastorant. De psycholoog Carl Rogers (1959:184-256) spreekt over een onvoorwaardelijke acceptatie. Op die manier hoeft de pastorant geen waarden en verwachtingen te introduceren die niet haar ervaring zijn, maar kan de pastorant gewoon zichzelf zijn met haar eigen ervaringen, ook als die niet positief zijn.

Daarnaast geeft Rogers aan dat er een congruentie moet zijn tussen verbale en non-verbale communicatie. Lichaamstaal en intonatie zijn erg belangrijk. Er moet sprake zijn van oprechtheid. Een pastor kan niet doen alsof - dat geeft geen blijk van respect voor de pastorant en schept geen gevoel van veiligheid, terwijl dat gevoel van veiligheid het meest belangrijke is voor de pastorale relatie. Wanneer de pastorant zich bedreigt voelt, zal ze de bekende manieren van overleven niet loslaten en zal ze nieuw kwetsbaar gedrag vertonen. Hoe kunnen pastors een veilige omgeving scheppen voor pastoranten? In de eerste plaats moet er sprake zijn van een beschermde omgeving. De tweede voorwaarde is dat pastors duidelijk zijn over hun manier van werken. Dat kan door de stijl van werken en de voorwaarden uit te leggen. De derde voorwaarde voor veiligheid is het respectvol en voorzichtig luisteren naar de zorgen en bezwaren van pastoranten. Als vierde en laatste punt is het belangrijk dat pastors een verbaal contract met de pastoranten sluiten dat haar de controle over het gesprek geeft (Neuger 2001:49).

Andere voorwaarden voor verandering zijn onder andere dat de pastorant moet ervaren dat iets niet werkt en dus verandering nodig heeft. Daarnaast heeft de pastorant de hoop nodig (of moet de hoop gegeven worden) dat een betere situatie kan ontstaan. Dit maakt het voor de pastorant de moeite waard om het counselingsproces te doorlopen. Een pastor kan veronderstellen dat er hoop is voor de pastorant, maar dan moet die hoop wel binnen afzienbare tijd substantie krijgen zodat de pastorant op korte termijn vertrouwen krijgt in het counseling proces. Verder moet er een duidelijke visie zijn over hoe de positieve veranderingen eruit zien. Zo krijgt de pastorant niet alleen energie om het counselingsproces vol te houden maar heeft ze ook de mogelijkheid om keuzes te maken over de richting van het proces. De pastorant moet weten dat de veranderingen niet in conflict staan met de waarden en positieve zelf-beelden van zichzelf. De voorwaarden voor veranderingen zijn de bevestiging van de waarden 
die belangrijk zijn voor de pastorant. Het is belangrijk dat de pastorant ervan verzekerd wordt dat ze de dingen die voor haar waardevol zijn niet zal verliezen. Daarnaast is het creëren van een plaats of kennen van een veilige plaats waar de pastorant haar positieve veranderingen en houdingen in de praktijk kan brengen, nieuwe zelfbeelden uit kan testen en kan experimenteren met nieuwe gevoelens. Dit kan bijvoorbeeld in een vrouwengroep zijn. Pastoranten zijn vaak bang voor vergelding vanuit de omgeving en dat is niet onterecht. Tot slot is het noodzakelijk dat pastors aan de pastorant vertellen dat zij de complexiteit van haar persoon zien en de complexiteit van haar verhaal erkennen. Het verhaal dat gehoord wordt, is het verhaal van de pastorant, niet de projectie van de pastor en diens vooronderstellingen over het verhaal. Daarom moet de pastor voorzichtig luisteren en zich bewust zijn van eigen waarden en normen en is het belangrijk regelmatig te checken of de pastor het verhaal juist heeft begrepen.

\section{- Dynamieken van verandering}

Er zijn verschillende raamwerken voor de verschillende theorieën over counseling waarin veranderingen voorkomen. De narratieve methode heeft zijn eigen raamwerk. Desalnietemin begint iedere vorm van counseling met het vertellen van het verhaal. In de narratieve methode wordt er geluisterd naar het geïnternaliseerde probleem van de pastorant. De taak van de pastor is om het probleem te externaliseren. Daarnaast gaat de pastor op zoek naar de "unique outcomes" om zo het probleem te deconstrueren en te reframen tot een nieuw positief verhaal dat kan worden geïntegreerd en versterkt.

Pastors zullen zich altijd moeten herinneren dat de narratieve theorie veronderstelt dat mensen hun eigen verhalen construeren en dat er geen essentiële waarheid is. Er zijn alleen interpretaties van de gebeurtenissen die echt zijn. Deze interpretaties leiden tot antwoorden op deze gebeurtenissen. De narratieve theorie veronderstelt dat mensen veel ervaringen hebben in hun leven die hun verhaal zouden kunnen uitdagen en kunnen sturen naar nieuwe interpretaties en betekenissen. Deze verhalen worden alleen niet "verhaald" omdat ze in conflict zijn met hun dominante kernverhaal.

Over het algemeen helpt de pastor de pastorant om haar onverhaalde levenservaringen te herontdekken en die uit te dagen, aan te vullen of zelfs het probleemverhaal te vernietigen. Dit wordt gedaan vanuit een niet-weten houding van de pastor. Vragen komen voort uit het zich afvragen. De pastorant is de partner die de kennis en het 


\section{Ontferming "beyond" vergeving als weg naar heling en heelheid}

raamwerk heeft om betekenis te geven. Deze kennis is echter verborgen. De pastor werkt door een nieuwsgierige, met ontferming bewogen, geïnteresseerde advocaat te zijn aan de kant van de pastorant. Zo kunnen pastorant en pastor samen uitzoeken hoe de kracht van het probleem kan worden weerstaan en hoe de positieve betekenisvolle elementen in het leven van de pastorant "herverhaald" kunnen worden. Vervolgens is het de taak van de pastor om de pastorant te helpen om het toe te passen in het leven (Neuger 2001:54$55)$.

\subsubsection{Theologie}

ledere pastor heeft zijn of haar eigen theologie die hem of haar leidt in het pastoraat. Het is belangrijk dat pastors zich ervan bewust zijn hoe hun theologie hun pastorale werk beïnvloedt. Het vormt de manier waarop ze naar pastoranten luisteren en de richting die ze kiezen in hun pogingen om te helpen. Neuger (2001:57) maakt gebruik van vier pastorale thema's die haar helpen in het pastoraat. Zij benadrukt dat deze thema's niet universeel zijn maar slechts vanuit haar geschiedenis en ervaring ontstaan zijn. ledere pastor heeft zijn of haar eigen thema's.

Het eerste thema wat Neuger beschrijft, is dat de genade van God vooraf gaat aan alles. Gods liefde voor mensen omvat mensen al voordat ze weten dat ze bestaan. Die genade van God hebben we nodig om te beantwoorden aan Gods zorg en acceptatie. Dit, in tegenstelling tot alle boodschappen van niet-waardevol zijn die vrouwen vanuit de cultuur ontvangen, geeft voor de vrouwen een boodschap van waarde. Het vertelt de pastorant dat haar realiteit de realiteit is, dat die realiteit serieus wordt genomen en dat haar ervaring waardevol is (Neuger 2001:57-58).

Het probleem van dit uitgangspunt is dat veel vrouwen die seksueel misbruikt zijn weinig of niets meer met God kunnen. Neuger noemt een aantal theologische problemen. Één daarvan is de beeldvorming van God. Vele vrouwen hebben geleerd dat God de Vader de controle heeft over de wereld en over hun leven. Op die manier kan de rol van God in het misbruik maar op twee manieren worden geïnterpreteerd. De eerste manier is dat God aan de kant van de mannelijke geweldenaar staat. Wanneer vrouwen misbruikt zijn door hun vader, volgt vaak de identificatie van hun vader met God de Vader. God is een strenge Vader die je moet gehoorzamen en die goedkeurt wat er gebeurt. De tweede manier van interpretatie is, omdat God niet heeft ingegrepen, dat God net zo hulpeloos en onzichtbaar is als het slachtoffer zelf (Neuger 2001:97). Ze voelen zich in de steek gelaten door God. Het vertrouwen is weg. Waar is Gods genade, zorg en acceptatie als dit een 
vrouw overkomt? Vrouwen zijn vaak niet meer in staat om de genade van God te ervaren. Hoe moeten Gods zorg en acceptatie geïnterpreteerd worden als zoiets gebeurt? Vaak zijn vrouwen het geloof al helemaal kwijt geraakt.

Het tweede theologische thema van Neuger (2001:58-59) betreft de kracht van de gemeenschap in het lichaam van Christus. Alle mensen worden gevormd door een dynamische interactie met de mensen en groepen in ons leven. Vele gemeenschappen, waaronder ook kerkelijke, houden vrouwen voor dat ze minder waard zijn dan mannen. Er zijn echter ook geloofsgemeenschappen die wel waarlijk dienen als het lichaam van Christus en die de kracht van Gods liefde en gerechtigheid reflecteren. Daar kunnen vrouwen delen van hun eigen verhalen horen via anderen. Door deze verhalen te horen en gesteund te worden door de gemeenschap kunnen vrouwen gaan geloven in hun eigen waarde en ervaringen.

Het probleem wat hier ontstaat heeft, raakvlakken met het voorgaande thema. Het is heel moeilijk voor vrouwen die seksueel misbruikt zijn binnen een kerkelijke context om nog iets van het lichaam van Christus te ervaren. Men zou juist verwachten dat binnen een kerkelijke gemeenschap, die pretendeert het lichaam van Christus te zijn, dit soort dingen niet voorkomen. Dit schept ook de verwachting dat binnen kerkelijke gemeenschappen de cijfers wat betreft seksueel misbruik lager liggen. Er is helaas geen reden om aan te nemen dat dit ook daadwerkelijk zo is (Ganzevoort \& Veerman 1999:1). Wanneer een vrouw seksueel misbruikt wordt binnen een kerkelijke context dan is dit een grote schending van haar vertrouwen in dat lichaam van Christus. Daar komt nog bij dat, als een dergelijke situatie aan het licht komt, kerkelijke gemeenschappen vaak niet weten hoe om te reageren. Dit heeft als gevolg dat het slachtoffer nog meer buiten spel komt te staan en zich in de steek gelaten voelt. Hoe kunnen vrouwen ervan worden overtuigd dat er ook gemeenschappen zijn die functioneren volgens het lichaam van Christus? Helemaal wanneer het vertrouwen van vrouwen dusdanig geschonden is.

Het derde theologische thema is de rijkdom en complexiteit van de goddelijke presentie die te vinden is in de vele beelden van God. Door de beelden van God die we meedragen, ervaren wij en interpreteren wij onze relatie met God. Dit heeft voor vrouwen veel problemen opgeleverd. Dit komt omdat God door gebruik van bepaalde beelden voor mensen kan worden afgesloten: God als mannelijk, machtig en blank. Daar tegenover staat dat vrouwen en mannen geschapen zijn naar Gods beeld (Gen 1:27). De beelden die we van God hebben, zijn cruciaal. Niet alleen voor het ervaren van de goddelijke presentie, maar vooral ook voor het begrijpen van onszelf, onze plaats in de schepping en Gods doorgaande intenties voor onze wereld. Wanneer vrouwen kunnen ervaren dat ook zij geschapen zijn naar Gods 


\section{Ontferming "beyond" vergeving als weg naar heling en heelheid}

beeld, dan geeft dat ruimte om te zien dat God ook van hen houdt om wie ze zijn. Er is geen onderscheid voor God (Neuger 2001:59).

Het vierde theologische thema is dat van de Exodus. Het exodusverhaal heeft verschillende aspecten. In de eerste plaats gaat het om de beweging van een gemeenschap die in gevangenschap leeft en die onder het leiderschap van God naar de vrijheid wordt geleid. De chronologie van het exodusverhaal ligt daarin dat de mensen die de onderdrukking ervoeren in het diepste van hun pijn God aanriepen voor bevrijding. Door het leiderschap van Mozes, Aaron en Mirjam heeft God de gemeenschap uit hun positie van onderdrukking geleid in een situatie die hen in staat stelde een hoopvolle relatie aan te gaan met de medemens en met God. De gemeenschap heeft een nieuwe verantwoordelijkheid gekregen, een verantwoordelijkheid die gebouwd is op de mogelijkheid om de volheid van hun leven te zien en de keuzes die zichtbaar werden. In vergelijking met de pastorale counseling kan de pastorant zien dat ze in een wereld van onderdrukking leeft, die haar geest verstikt en haar keuzes beperkt. Vaak voelen pastoranten eerst grote pijn voordat ze zich hiervan bewust worden. De counseling ervaring behelst een intense reis om bevrijding te vinden en bemoediging, niet als individu maar als gemeenschap en cultuur. Zo krijgen zij een nieuwe verantwoordelijkheid. Vanuit die nieuwe ruimte gaan vrouwen terug naar dat land van onderdrukking om andere verhalen te horen en die mensen te helpen met hun reis (Neuger 2001:60-61).

Het is belangrijk dat pastors hun eigen theologische standpunten en uitgangspunten kennen en waarderen. Deze standpunten staan niet op zichzelf. Zij bestaan in een gemeenschap van steun en verantwoordelijkheid waar het pastoraat plaatsvindt. Het is de verantwoordelijkheid van pastors om de pastorant haar eigen theologische standpunten die haar leven bepalen te laten ontdekken, te laten indentificeren en ze beschikbaar maken voor onderzoek en groei.

Neuger (2001:61-63) maakt hiervoor gebruik van vijf theologische vragen die zij behulpzaam vindt in het counseling proces. Om te beginnen is het goed om te realiseren dat theologie en religie het centrum zijn van het pastorale counseling proces en niet slechts een randvoorwaarde. Het heeft lang in de schaduw gestaan van de psychologie. Het probleem is alleen dat er niet gewerkt is aan relevante theologische taal voor het pastorale counselingproces, dit ten opzichte van de psychologische terminologie die continu is vernieuwd.

De eerste vraag is: "wat staat er op het spel?" Deze vraag gaat terug achter de gedragingen, gevoelens en gedachten die het probleem presenteren. Het stelt de diepere vraag naar het beeld wat de pastorant heeft 
van de risico's, de doelen, de mogelijkheden en de "horrors" die de basis vormen voor de beslissingen die ze neemt - het vraagt naar de bron van haar diepste bedoelingen en haar diepste angsten. Deze vraag breekt door de verdediging en rationalisaties en draagt ertoe bij om te komen bij de centrale beelden die de psychologische, spirituele, fysische, relationele, systematische en culturele dimensies van het zelf samenbinden. In het centrum bevindt zich het spirituele, de ultieme betekenis wat op het spel staat in het dilemma, crisis, besluit of overgang.

De tweede vraag luidt: "Wat is het beeld van de pastorant over hoe God haar waarneemt?" Deze vraag komt in plaats van wat haar Godsbeeld is. Door de vraag zo om te draaien komen we tot een dieper punt in de relatie tot God.

De derde en vierde vragen zijn nauw met elkaar verbonden: "Hoe ervaart een persoon Gods genade in haar leven?" en "Hoe ervaart een persoon Gods oordeel in haar leven?" Door deze twee vragen krijgt de pastor een beeld van de vooronderstellingen die de pastorant automatisch aanneemt over de waarde en morele goedheid van haar levensactiviteiten.

De vijfde en laatste vraag is: "Hoe ziet de persoon zichzelf in verhouding met de rest van de gemeenschap?" Is de verbinding geschikt? Is er een juiste emotionele, fysische en intellectuele afstand? Is er samenhang en wederkerigheid of is er sprake van afscheiding en autonomie? Is er isolatie? Hoe functioneert de gemeenschap en hoe heeft het de pastorant gevormd tot de persoon die ze nu is? Deze vragen presenteren een manier om primair theologisch te framen in de taak van het counselen.

De vraag is echter; hoe kan een pastor aan de hand van deze vragen theologisch reframen in het counselen? Neuger (2001:97-102) haalt een aantal theologische problemen aan. Zij schrijft onder andere over de beeldvorming van God, de hiërarchie in de kerk, de problemen van een christelijke achtergrond en over vergeving. Zij beschrijft echter niet de gevolgen van de theologische standpunten van pastors met betrekking tot deze onderwerpen. Er kan pas een helende reframing plaatsvinden bij de pastorant wanneer de pastor helende theologische denkbeelden heeft. Als pastors helende theologische denkbeelden hebben, hoe kunnen zij deze toepassen in het pastoraat om te helpen bij een helende reframing? Om meer duidelijkheid te krijgen over deze vragen wordt het narratieve model van de filosoof Paul Ricoeur beschreven.

\subsection{Het model van Paul Ricoeur}

De narratieve methode is een postmoderne benadering tot counselen. Dat wil zeggen, er is geen absolute objectiviteit mogelijk. Voor het narratief counselen 


\section{Ontferming "beyond" vergeving als weg naar heling en heelheid}

houdt dat in dat pastors hun eigen verhalen meedragen in het counselingsproces. Alles is interpretatie. Naast de erkenning dat absolute objectiviteit onmogelijk is, heeft de "linguistic turn" plaatsgevonden, dat wil zeggen het besef dat alles wordt uitgedrukt in taal en de consequenties daarvan. Er vindt een beweging plaats naar het gebruik van figuratieve taal, zoals het gebruik van metaforen en narrativiteit (Stiver 2001:12).

De waarde van het werk van Ricoeur ligt als zodanig niet in zijn theologische inzichten, maar in het feit dat zijn filosofische raamwerk een bron is voor het hele theologische spectrum (Stiver 2001:2). Voor dit onderzoek wordt gebruik gemaakt van dat deel van zijn filosofische raamwerk waar hij ingaat op het hermeneutische proces van narrativiteit. Om te begrijpen waar zijn inzichten vandaan komen wordt er eerst in vogelvlucht een overzicht gegeven van de geschiedenis van de hermeneutiek.

De geschiedenis van de hermeneutiek begint bij Friedrich Schleiermacher. Hij is de grondlegger van de theorie van de interpretatie (zie Stiver 2001:35). Schleiermacher heeft voor een belangrijke wending in de hermeneutiek gezorgd. Hij is diegene geweest die het verschil heeft uitgewerkt tussen de grammaticale hermeneutiek en de psychologische hermeneutiek (Thiselton 1992:217). De grammaticale hermeneutiek is de "objectieve" interpretatie. Daaronder vallen onder andere de taalkundige analyse, culturele en historische gegevens ("objectiverende" gerichtheid van de exegese) (Van Aarde 2003:551). De psychologische hermeneutiek bestudeert taal als uitdrukking van het "persoonlijke leven", het is "subjectief". Het gaat hier om de gevoelens van de participanten in het proces van communicatie (Van Aarde 2003:552). De psychologische hermeneutiek wil uitkomen bij de "identiteit van het zijn" of zoals Martin Heidegger (Heidegger 1962:42, 44; vgl Inwood 2000:20-30) het noemt: Dasein.

Heidegger is hierop doorgegaan. Hij gaat ervan uit dat ieder mens een verhaal is dat geschreven is door de tijd heen. We zijn continu bezig met schrijven en herzien van het verhaal in het licht van de ervaring. De pogingen van het bewustzijn om onszelf te interpreteren zijn niet vrije creaties maar herschrijvingen van een verhaal wat al vele hoofstukken bevat. D R Stiver (2001:39) beschrijft het als volgt: "We always experience the present influenced by our memories of the past and our projections into the future. We experience the world in terms of retentions and potentions, al part of our intentions."

Hans-Georg Gadamer en Paul Ricoeur gaan nog verder. Zij geven het snijpunt tussen de hermeneutiek en de fenomenologie weer. Dit resulteert in een wezenlijke hermeneutische filosofie (zie Stiver 2001:40-45). Gadamer (1989101-134) gebruikt de metafoor van het spelen van een spel. Er is 
interactie tussen de tekst en de lezer. Wij als lezer spelen het spel niet maar het spel speelt ons. In termen van het hermeneutische spel betekent het dat de zaak (Sache) van de tekst niet iets is dat volledig in het beheer van de lezer is.

Bij het lezen van een tekst vindt volgens Gadamer (1989:302-307; vgl Stiver 2001:45-50) een horizonversmelting plaats, een versmelting van de eigen horizon bestaande uit aannames, cultuur en tradities met de horizon van de tekst. Wij verstaan een andere horizon door onze eigen horizon heen. leder mens is gevormd door traditie en kan daar niet aan ontsnappen. Tradities geven ons de vooronderstellingen die op hun beurt ons de mogelijkheid geven om te verstaan.

De visie van Ricoeur is verwant met die van Gadamer. Ook Ricoeur gaat ervan uit dat we niet de controle over de interpretatie hebben, we worden "gespeeld". Hij maakt dit duidelijk door de introductie van "de hermeneutische boog". Ricoeur ziet dat als een drievoudig proces bestaande uit: mimesis 1 (prefiguratie), mimesis 2 (configuratie) en mimesis 3 (refiguratie). De mimesis 1 is een soort inleidende bevoegdheid waarmee een verhaal benaderd wordt. Er worden vragen gesteld als: "wat", "waarom", "wie", "hoe", "met wie" en "tegen wie". Deze vragen kan de lezer stellen, omdat de lezer begrip heeft van de praktijk (practical understanding). Dit zijn de vooronderstellingen die Gadamer noemt - de vooronderstellingen die ons in staat stellen om te verstaan. De lezer verwacht dat karakters bepaalde motieven hebben voor hun handelen.

De mimesis 2 opent het rijk van de fictie. Hier gaat het om de gedachte van het verhaal, gebeurtenissen moeten aan elkaar gerelateerd worden. Waarom gebeurt het een na het ander? Vanuit het eindpunt van het verhaal kan het verhaal en zijn betekenis gezien worden als geheel. In mimesis 1 ging het om de verwachtingen die de lezer heeft van een karakter. In mimesis 2 wordt duidelijk of het karakter inderdaad zo gehandeld heeft als verwacht en wat de redenen daarvoor zijn. Dit wordt duidelijk bij het terugkijken op het verhaal. Een verhaal op zich is niets, de lezer moet het laten gebeuren door het te lezen.

De mimesis 3 is het snijpunt tussen de wereld van de tekst en de wereld van de lezer, de toepassing van de wereld van de tekst in de echt wereld. Er is een moment in het lezen of horen van het verhaal dat reikt naar achter het verhaal zelf. Als een verhaal niet deze verwijzende functie heeft, dan is het doel verloren en dan zou de lezer/hoorder de diepere betekenis niet begrijpen (vgl Simms 2003:84-86).

Dit moment ontbreekt in het pastorale model van Neuger. Hoe kan de pastor met de pastorant "beyond" het verhaal komen: "beyond" het verhaal 


\section{Ontferming "beyond" vergeving als weg naar heling en heelheid}

van de pastorant, "beyond" de theologische denkbeelden, "beyond" het verhaal van de bijbel zelf? Daar vindt de reframing plaats van het verhaal van de pastorant, zodat de pastorant heling kan ervaren. Volgens Simms (2003:86) is mimesis 2 de belangrijkste fase in het model, want het opent de weg naar fictie en het bemiddelt tussen mimesis 1 en mimesis 3. Mimesis 1 is ons "voorafgaande begrijpen" of in het beeld van Gadamer onze eigen horizon met onze aannames, cultuur en tradities waarmee de lezer het verhaal benadert. Mimesis 3 is het verstaan van de wereld na het lezen van het verhaal, het nieuwe verstaan van de wereld als resultaat van het lezen en het begrijpen van het verhaal. Mimesis 2 is het proces er tussen in. Hier worden alle evenementen en gebeurtenissen gerangschikt tot een verhaal. Daarom kan de lezer het verhaal als verhaal begrijpen en het verhaal als nabootsing zien van de echte wereld. Het laat de lezer zien dat de acties die afgetekend worden in het verhaal, menselijke acties zijn. Samengevat: de prefiguratie is geconfigureerd in de refiguratie. Het heden is de anticipatie van de toekomst bemiddeld door de herinnering van het verleden.

\section{BEVINDING GEANTICIPEERD}

Voor een vrouw die sexueel misbruikt werd binnen een kerkelijke gemeenschap is het verleden het verhaal van misbruik. Het heden is dat zij haar steeds bevindt in de kerkelijke gemeenschap die deze situatie moet hanteren en de vrouw pastoraal moet begeleiden. Vaak wordt in de pastorale begeleiding van een christenvrouw gevraagd om te vergeven. Als de pastorant dit niet kan - en dit is vaak het geval - betekent het dat zij blijft steken in de "herinnering van het verleden". Zij is niet gekomen tot de weg van heling en heelheid.

Hier komt de onderzoeksvraag terug. Het is noodzakelijk om "beyond" het verhaal van de pastorant te komen, "beyond" de theologische denkbeelden, "beyond" het verhaal van de bijbel zelf en "beyond" de vragen over vergeving. Wat zijn de theologische implicaties van vergeving en waar is de plaats van de pastor in dit geheel? Hoe kan de pastor de pastorant helpen om "beyond" haar verhaal te komen? Om te kijken wat voor theologische denkbeelden er onder andere in het pastoraat voorkomen, wordt er in een volgende artikel een bijbels-theologisch model vanuit het Mattheüsevangelie beschreven. Daarin worden de begrippen schuld en vergeving belicht. Tot slot wordt een model voor narratief-pastorale bemachtiging voorgesteld opdat reframing als weg tot heling en heelheid kan plaatsvinden. 


\section{Lijst van aangehaalde werken}

Adams, C J 1994. Woman battering. Minneapolis, MN: Fortress Press.

Ballou, M \& Gabalac, N W 1985. A feminist position on mental health. Springfield, Il: Charles C Thomas.

Bons-Storm, R 1992. Pastoraat als bondgenootschap: Aanzet tot vernieuwing van de kerkelijke praktijk vanuit het vrouwenpastoraat. Kampen: Kok.

Derrida, J 1978. Writing and difference, vertaald door A Bass. Londen: Routledge.

Epston, D \& White, M 1990. Narrative means to therapeutic ends. New York: Norton.

Freedman, J \& Combs, G 1996. Narrative therapy: The social construction of preferred realities, New York: Norton.

Gadamer, H-G 1989. Truth and method, vertaald door J Weinsheimer \& G Marshall. $2^{\mathrm{e}}$ herziene editie. New York: Continuum.

Ganzevoort, R R \& Veerman, A L 1999. Geschonden lichaam: Pastorale gids voor gemeenten die geconfronteerd worden met seksueel geweld. Zoetermeer: Boekencentrum.

Greenspan, M 1983. A new approach to women in therapy. New York: McGraw-Hill. Heidgegger, M 1962. Being and time, vertaald door J Macquarrie \& E Robinson. Oxford: Oxford University Press.

Heitink, G 1990. Geloof en geestelijke gezondheid, in Heitink, G \& Veenhof, J (reds), Heil, heling, gezondheid. Den Haag: Meinema.

Holder, D P \& Anderson, C M 1989. Women, work and family, in Goldrick, M, Anderson, C M \& Walsh, F (eds), Women in families: A framework for family therapy, 357-380. New York: W W Norton.

Inwood, M 2000. Heidegger: A very short introduction. Oxford: Oxford University Press.

Monk, G, Winslade, G, Crocket, K \& Epston, D (eds) 1997. Narrative therapy in practice: The archaeology of hope. San Francisco, CA: Jossey-Bass.

Müller, J 2000. Reisgeselskap: Die kuns van verhalende pastorale gespreksvoering. Wellington: Lux Verbi.

Nelson, J B 1988. The intimate connection: Male sexuality, masculine spirituality. Philadelphia, PA: Westminster.

Neuger, C C 2001. Counseling women: A narrative pastoral approach. Minneapolis, $\mathrm{MN}$ : Fortress.

Nynke, een liefdesgeschiedenis, geregisseerd door P Verhoeff, Egmond film 2001.

Rogers, C 1959. A theory of therapy, personality, and interpersonal relationships as developed in the client-centered framework, in Koch, S (ed), Psychology: A study of a science, 184-256. New York: McGraw-Hill.

Simms, K 2003. Paul Ricoeur. Londen: Routledge.

Stiver, D R 2001. Theology after Ricoeur. Louisville, KY: Westminster John Knox.

Thiselton, A C 1992. New horizons in hermeneutics: The theory and practice of transforming biblical reading. London: HarperCollins.

Van Aarde, A G 2003. Die ou-Kersaandgesprek van Friedrich Schleiermacher in Afrikaans: Agtergrond, vertaling en hermeneutiek. HTS 59(2), 545-568.

Van der Schaaf, T S \& Deyer, Y [2004]. Ontferming "beyond" vergeving als weg naar heling en heelheid: "Reframing" als narratief-pastorale bemachtiging.

Publicatie in HTS bepland. 